\title{
Soil Water Studies on Oxisols and Ultisols of Puerto Rico: IV. A Comparison of Techniques to Determine Water Retention at Various Tensions ${ }^{1}$
}

\author{
James $M$. Wolf and Matthew Drosdoff ${ }^{2}$
}

\begin{abstract}
An over estimation of soil water storage would be made by employing either disturbed sample techniques at low tensions or undisturbed core samples at high tensions. To avoid this, undisturbed core samples should be used to measure water retention in the wet range ( 0 to 1 bar) and disturbed samples, to measure water retention in the dry range ( 1 to 15 bars). It is suggested that soil water release curves be developed by relating field measurements of soil water tension with results from gravimetric sampling.
\end{abstract}

\section{INTRODUCTION}

The purpose of the soil water experiments conducted recently in Puerto Rico was to determine the water supplying characteristics of four soils on which fertility experimentation was in progress. The results of the field and laboratory work have been reported in three previous papers by Wolf and Drosdoff $(2,3,4)$.

This paper reports on a comparison of laboratory techniques to measure water retention in the wet and dry ranges, i.e., 0 to 1 and 1 to 15 bars of tension. The study compared disturbed and undisturbed samples using various methods.

\section{MATERIALS AND METHODS}

Information as to the soils and the laboratory techniques used can be obtained from Wolf and Drosdoff (2).

${ }^{1}$ Submitted to Editorial Board April 25, 1975.

${ }^{2}$ Formerly Lecturer, Department of Agricultural Engineering, now with CIDIAT, Mérida, Venezuela, and Professor of Soil Science, Department of Agronomy, respectively, Cornell University, Ithaca, N.Y., in cooperation with the Agricultural Experiment Station of the University of Puerto Rico and with the support of the U.S. Agency for International Development under Research Contract csd 2490. The authors are indebted to several people for assistance during the course of the work. Dr. Richard Fox was singularly helpful in providing logistic support. Gaston Amedée assisted greatly in both the laboratory and field. Drs. Levine and Bouldin willingly gave their time in reviewing this material. Many other people at Río Piedras, Corozal, and the other sites gave assistance when needed. Special thanks are due to Dr. Miguel A. Lugo-López for his assistance in preparing the manuscript for publication. Lastly, the senior author acknowledges the continued support by the Agricultural Engineering Department, Cornell University, which enabled him to undertake this work. 
The comparison of techniques used to determine water retention at various tensions were the following:

1) Disturbed samples on pressure plate apparatus at $1 / 3,2 / 3,1,5,15$ bars;

2) Undisturbed samples $(7.62 \times 7.62 \mathrm{~cm}$ core samples $)$ on

a) Tempe cells, 0 to $3 / 4$ bars tension

b) Pressure plate apparatus, 0 to 15 bars tension.

\section{RESULTS AND DISCUSSION}

In the tension range 0 to $3 / 4$ bar, volumetric outflow from cores run on Tempe cells compared favorably with weight changes in cores placed on pressure plate apparatus and dewatered. The methods appeared to give similar results over this tension range.

If both methods are available, Tempe cells may be easier to run since frequent weighings are not required. However, since the cells are specialized equipment, it may be more convenient to run core samples on the pressure plate apparatus.

In the tension range 1 to 15 bars, the undisturbed core samples run on the pressure plate apparatus did not dewater to the extent that disturbed samples dewatered. The fact that the cores did not adequately dewater although they remained under 15 bars pressure for up to 2 weeks, is probably due to the height of the core $(7.62 \mathrm{~cm})$ and to low capillary conductivity at high tensions. Disturbed cores have a larger percentage of their volume in contact with the plate, permitting faster dewatering. Water contents determined by 15 -bar disturbed samples have been well correlated with permanent wilting in the field. (For example, see MacLean and Yager (1).) Therefore, that method is preferred. In the tension range 0 to $3 / 4$ bar, disturbed samples over estimated the amount of water retained when compared to that retained by the undisturbed core samples.

Typically, at zero tension (saturation) 90 to $95 \%$ of the voids (pores) of undisturbed samples were filled with water. The remainder were filled with entrapped air. Similar calculations were made using water contents at saturation from disturbed samples and bulk density measurements from undisturbed cores. These would indicate that disturbed samples had 100 to $125 \%$ of the undisturbed voids filled with water, an obvious impossibility. In conclusion, disturbed samples should be used for water release characterization in the range 1 to 15 bars of tension. Undisturbed core samples can be used in the range 0 to 1 bar.

As an alternative to running soil water release curves in the laboratory, soil tensions obtained using tensiometers could be directly related to soil water content through a program of gravimetric soil sampling. This should be done for all depths and over a wide range of water contents and 
would require a growing crop and irrigations. Bulk density measurements would have to be made.

The value of this approach is twofold: 1) It circumvents the time-consuming laboratory processes and delicate handling required for undisturbed soil cores; and 2) it provides a direct correlation between tension and field soil water content. The upper limit of tensiometers is about 0.8 bar. At higher tensions readings from resistance blocks or information from neutron probe equipment can be correlated with gravimetric soil water contents. Although there was good correlation between field sampling for water contents and indirect measurements using tensiometers and laboratory determined soil water release curves, it is suggested that values of soil water tension be directly related to water contents through extensive gravimetric sampling.

\section{RESUMEN}

Se compararon técnicas de laboratorio para medir la retención de agua de 0-1 y de 1-15 bares de tensión. Se utilizaron muestras en su condición natural y muestras en que se alteró dicha condición.

Se concluye de la evidencia obtenida que se deben usar muestras en su condición natural (columnas) para medir la retención de agua de $0-1$ bar y muestras en que se altera dicha condición natural para medir la retención de agua entre 1-15 bares. Si se usan muestras en su condición natural con las tensiones altas y muestras cuya condición ha sido alterada con las tensiones bajas, se corre el riesgo de sobreestimar la capacidad de almacenamiento de agua del suelo. Se sugiere que las curvas de liberación de agua del suelo se desarrollen relacionando las mediciones de campo de la tensión a la cual el agua es retenida con los resultados de los análisis gravimétricos correspondientes.

\section{LITERATURE CITED}

1. MacLean, A. H., and Yager, T. U., Available water capacities of Zambian soils in relation to pressure plate measurements and particle size analysis, Soil Sci. 113: 23-9, 1972.

2. Wolf, J. M., and Drosdoff, M., Soil water studies on Oxisols and Ultisols of Puerto Rico: I. Water Movement, J. Agr. Univ. P.R. 60 (3): 375-85, 1976.

3. $\longrightarrow$ and $\longrightarrow$ Soil water studies on Oxisols and Ultisols of Puerto Rico: II. Moisture retention and availability, J. Agr. Univ. P.R. 60 (3): 386-94, 1976.

4. — and $\longrightarrow$ Soil water studies on Oxisols and Ultisols of Puerto Rico: III. Capillary conductivity, J. Agr. Univ. P.R. 60 (4): 508-12, 1976. 